\title{
Studies on the Asian Regional Monetary Unification \& ACU Model based on the [10+4] FTA Initiative
}

Abstract- Though the phenomenon of "Counter-Globalization" occurred recently, economic globalization and regional economic integration are still the trends, especially as shown by the Asian economic integration process. The Asian regionalization is in very initial stage emerging in various cooperation mechanisms, forming a multi-level pattern of coexistence in the later erupted advantage.

Based on the theories of regional economics and the Optimal Currency Zone, within the $[10+4]$ FTA considered frame inc. The ASEAN, China, India, Japan, and South Korea, an academic study is carried out comparing with the case of the European regionalization. The research will focus on conditions and barriers in the Asian currency unification process, and finally a corresponding step proposal to set up "the ACU Experimental Zones" together with a model is putting forward.

Keywords: the [10+4]; unified currency; conditions; barriers; experimental zones; model.

GJHSS-H Classification: FOR Code: 910108

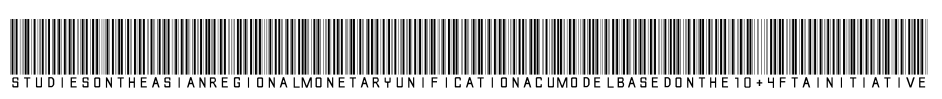

Strictly as per the compliance and regulations of:

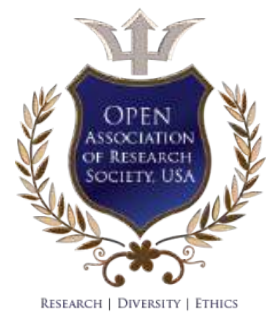

(c) 2020. Yao Chaocheng \& Deng Yi. This is a research/review paper, distributed under the terms of the Creative Commons Attribution-Noncommercial 3.0 Unported License http://creativecommons.org/licenses/by-nc/3.0/), permitting all non-commercial use, distribution, and reproduction in any medium, provided the original work is properly cited. 


\title{
Studies on the Asian Regional Monetary Unification \& ACU Model based on the $[10+4]$ FTA Initiative
}

\author{
Yao Chaocheng ${ }^{\alpha} \&$ Deng $Y i^{\sigma}$
}

Abstract-Though the phenomenon of "Counter-Globalization" occurred recently, economic globalization and regional economic integration are still the trends, especially as shown by the Asian economic integration process. The Asian regionalization is in very initial stage emerging in various cooperation mechanisms, forming a multi-level pattern of coexistence in the later erupted advantage.

Based on the theories of regional economics and the Optimal Currency Zone, within the [10+4] FTA considered frame inc. The ASEAN, China, India, Japan, and South Korea, an academic study is carried out comparing with the case of the European regionalization. The research will focus on conditions and barriers in the Asian currency unification process, and finally a corresponding step proposal to set up "the ACU Experimental Zones" together with a model is putting forward.

Keywords: the [10+4]; unified currency; conditions; barriers; experimental zones; model.

\section{Academic Theoretical Review}

R egional monetary integration theory (the Optimal Currency Zone) had been proposed as the earliest by Robert Mondale, the Nobel economic prize winner in 1961, and it is still the guiding theory nowadays. Mondale believed that free flow of production elements is the critical criterion for an optimal currency zone. Later on, some economists like McKinnon, Dram, Hubble, and Fleming made supplements and corrections to Mondale's opinion from different aspects. As McKinnon proposed in particular that, to determine the criteria of the Optimal Currency Zone $(\mathrm{OCZ})$ is the opening standard of economies in the OCZ, and the cost of membership means to lose some of their economic sovereignty [1]. It was these supplements and corrections that give completeness of the theory.

In 2003, when the Asian economic integration in the beginning time, Mondale made his prediction that the world in the future would have three major currency zones, the Euro, the USD, and the Asian Currency. The concept of the Asian Currency aroused an intensified academic discussion worldwide then. In 2004, Mr. Sakakibara, director of the International Financial Office,

Author a: (1953), Professor (Retired) and Ph.D in economics, Shanxi University of Finance \& Economics, China.

e-mail:yaochaocheng@vip.sina.com

Author o: (1975), Sichuan NMLK High-teach Research Institute. e-mail: 44962504@qq.com
Ministry of Finance of Japan, famous as known as "Mr. Yen," said that, in consideration of the medium and long run, Asian countries are likely to have their common currency unit [2]. One of the issues in the 2005' Boao Asia Forum held in the city of Hainan, China, was about the Asian currency integration and the possibility of issuing the Asian Currency Unit (ACU). Mr. LONG Yongtu, the former Secretary-General of the Forum, stated as such, " the ACU should be pursued as a longterm goal, and it worth pursuing for two reasons: (1) $70 \%$ of foreign exchange reserves of the world are in Asia. If Asian nations could have their own unified currency and be stable, that would be good for Asia; (2) So far, there are only USD and the Euro to be the hard currencies. If the ACU established, China's foreign exchange reserve shall give a third option. It shall form the situation of the three pillars of the global hard currency system [3]".

In 2005, the Asian Development Bank (ADB) compiled the Asian Currency Unit (ACU) by combining 13 different currencies of Asian countries in a weighted average method. It became the "prototype" of the Asian Currency [4].

Professor LU Jian-Ren, a researcher of AsianPacific Studies Institute of the China Social Science Academy, said in his paper, "the former India Prime Minister Singh pointed out as early as in 2004 in the 3rd China-ASEAN Business Summit that the predicted Asian Economic Community would have to include China, Japan, South Korea, the ASEAN as well as India. The proposed community would account for half of the world's population, the trade volume exceeding that of NAFTA, foreign exchange reserve volume be larger than the total of the EU and NAFTA". In 2009, Japan's former Prime Minister Hato Yama expressed respectively at the UN General Assembly and other occasions the concept of the East Asian Economic Community, and thought it necessary to create similar institution as the EU and a unified Currency like the Euro in Asia, to build up the East Asian Community [5].

On October 21, 2016, at an academic forum, Mr. ZHOU Qiang-Wu, director of the International Monetary Research Center, Financial Ministry of China, made his speech titled "Deepening the Asian financial cooperation and promoting the regionalization", saying as "Compared with European, Asian regional financial 
cooperation has been so delayed. Looking by now, Asia should have its common currency in the future, and the free labor and capital flow [6].

From above-mentioned review, the worldwide research about Asian monetary integration began in 2003, and the trend became hot in 2005-2006. Asian scholars and politicians then were generally believed that Asian economic integration in the primary stage with the relatively low opening degree of the regionalized economy. Not yet possessing the conditions of regional monetary unification, in long term Asia does need a unified currency. However, it should be implemented at bottom levels step by step.

\section{il. Current Situation of the Asian ECONOMIC INTEGRATION}

\section{a) The Concurrent Trend of the Economic Integration in} Asia

Since the 1990s, with the increased structural change of the world economy, the trend of regional economic integration gradually accelerated. It is the same in Asia. The ASEAN (Association of South-East Asian Nations) played role as an axle, and some major Asian countries such as China, Japan, Korea, and India were actively involved in the process. On August 8, 1967, five Asian nations, Indonesia, Thailand, Singapore, Philippines, and Malaysia, held their meeting of foreign ministers in Bangkok and stated founding the ASEAN, namely the Bangkok Declaration. After more than 50 years, the ASEAN has developed effective mechanisms and accumulated rich experience in the regionalization of ten member states. Since the signing the FTA agreement with South Korea in 2006, the ASEAN had ever signed the agreements respectively with Japan (2007), with China (2010) and with India (2014). The ASEAN Economic Community had been founded by the end of 2015 .

The current Asian economic integration shows in various forms, different ranges and levels of cooperation, in dimensional structure. In addition to the bilateral FTA agreements signed by the ASEAN with China, Japan, South Korea and India, there are also two pan-Asia multilateral cooperation schemes, the Regional Comprehensive Economic Partnership Agreements (RCEP) inc. sixteen countries and the Trans-Pacific Partnership (TPP), formerly had 12 countries participating, but now 11.

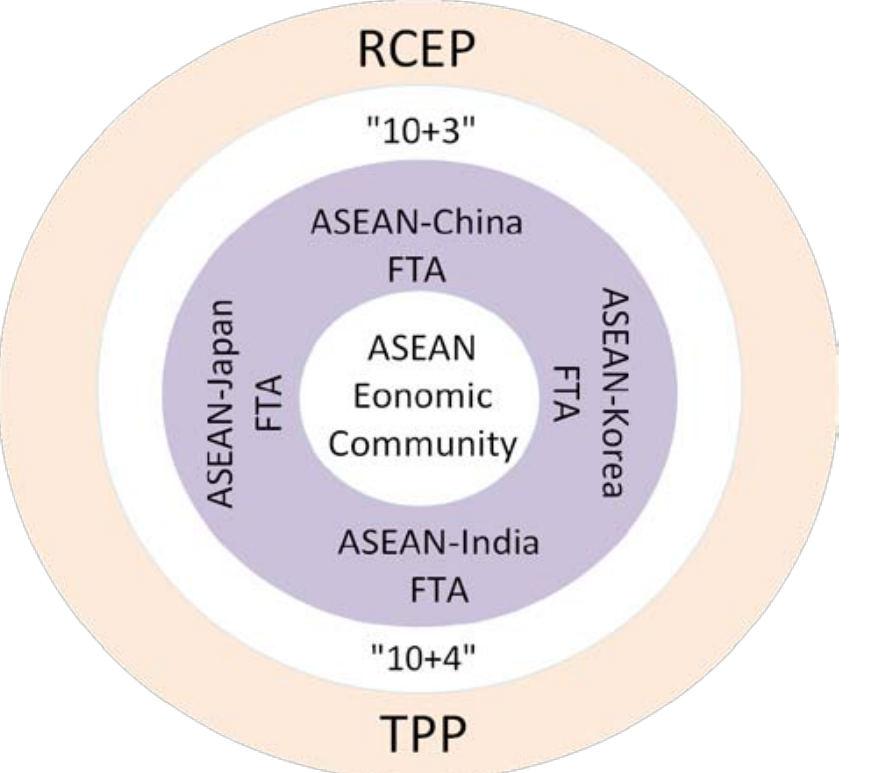

Figure 1: The Situation of Asian Regional Economic Integration

Against the quit of the US from the TPP, Asian countries, particularly China, Japan and India, are determined to further promote the Asian economic integration process. Therefore, the Asian regionalization trend will not be reversible. According to news reports, on May 21, 2017, 11 TPP members (excluding the US) had their ministers meeting in Hanoi, Vietnam, announcing their statement aiming to make the TPP agreements into effect as soon as possible. In the TPP meeting, ever held in Chile on March 14, 2017, it was the first meeting since the US withdrawal, proposing to open talks with China. China and South Korea, two non-TPP members, were invited to explore the future direction of the scheme. If the two to join the TPP, it shall be possible for integration of the TPP with the RCEP, eliminating the adverse factors, and bringing good outcome. In terms of market size and economic capacity, China will very likely become the real free trade leader of the Pan-Pacific rim [7].

b) Obstacles Faced by the Asian Monetary Integration The Asian monetary integration challenging the US Dollar hegemony fundamentally, it certainly shall 
encounter pressures and interventions from the US, the world's sole superpower. The US, by all means, will be setting up obstacles to maintain its position in the region, and to protect its interests in Asia.

Internal barriers to the Asian monetary integration are mainly reflected in three aspects, the unbalanced economic development among Asian countries and the ideological and cultural differences in the region. For example, within the $[10+4]$ domain, and the first and most important, within the 10 ASEAN member states, is the huge imbalances in economic developments. Among them, Singapore, Brunei and Thailand, are relatively developed, but Myanmar and Laos are far lag behind. According to Malaysia's statistic, the GDP Per Capita Deviation among ASEAN nations is 61 times showing the internal wealth gap between the richest and poorest, and that of the EU was only eight times [8].

When observing the geopolitical structure in Asia, it can be particularly noticed that the four neighboring countries, between China and Japan, Japan and South Korea, China and India, not only existing the political system differences, cultural differences, but also the territorial disputes. These shall be restricting the regional economic and monetary integration.

\section{ili. Analysis of Conditions of the Asian MONETARY InTEGRATION}

\section{a) On the Asian Monetary Integration Tendency}

The Asian Development Bank (ADB), as an intergovernmental institution in Asia and Pacific promoting economic and social development, belongs to 67 Asian member states, including the US. As early as in 2005, the bank had calculated value of the Asian Currency Unit (ACU) combining 13 Asian national currencies, with the method of weighted average and the ACU had been planned to be issued practically as the booking currency in the mid-2006 [9].

On May 3, 2009, the 12th Session of the [10+3] Finance Ministers' Meeting had been held in Bali Island, and a consensus reached for setting up the Asian regional foreign exchange reserve of $\$ 120$ billion to start the operation as scheduled by the end of 2009[10]. It was of significance to establish the Asian regional foreign exchange reserve to maintain regional economic and financial stability. This move made a positive impact on the reform of the international financial system. The Asian authorized reserve scheme is a monetary cooperation mechanism in the region, and is to imitate the form of the International Monetary Fund (IMF) to finally set up the Asian Monetary Fund as planned.

On October 24, 2014, the Asian Infrastructure Investment Bank (AllB) had been registered officially in Beijing. An agreement had been signed by finance ministers and authorized representatives of the 21 counties in firs-round inc. China, India, Singapore as founding members. The AllB is of intergovernmental nature, a regional and multilateral development agency, focusing on supporting Infrastructure projects, headquartered in Beijing with an authorized capital of $\$ 100$ billion. As of October 20, 2016, shareholders of the AllB had been increased to more than 80 , overtaking the ADB, which has 67 members. The establishment of the AllB will undoubtedly promote the Asian monetary integration process.

Another major event that happened in 2016 was the internationalization trend of the Chinese currency RBM. On June 7, 2016, China's central bank, the People's Bank of China, decided to provide RMB 250 billion to the USA as the Qualified Foreign Investor Quota (QFLL) to set up the RMB Trading Center in the USA, supporting the RMB clearing and settlements. At this point, the initial goal of the RMB internationalization had been uneasily and successfully making [10]. On November 30, 2016, Madam Lagarde of the former IMF Director announced officially the RMB to have been taken into the IMF's Special Drawing Rights (SDR) basket. Meanwhile, the People's Bank of China and the Ministry of Finance of China issued different policy measures, to meet the requirements of the IMF, including reviewing of the central parity rate mechanism, allowing foreign central Banks to deal all onshore banking products trading and issuing the three-month debentures in RMB, to improve their short-term yield curve [11]. The current IMF SDR basket includes the US dollar, Euro, Yen, Sterling Pounds and RMB. The Yen and $\mathrm{RMB}$ are two Asian currencies.

On October 21, 2016, Mr. ZHOU Qiang-Wu, director of the Center for International Finance of the Ministry of Finance of China, made a speech titled "Deepening the Asian Financial Cooperation and Promote the Regional Integration", and saying as "Globally, North America, Latin America, and even Africa are all doing the regional economic integration. In comparison, European integration has gone far in the world, representing the highest level of regionalization. Why could Europeans achieve this? The root cause is that after World War II, European nations would seek common ground while putting aside disputes, to be united." Mr. ZHOU further commented, "Compared with Europe, Asian regional financial cooperation started late. However, Asia now has the "10+3 " cooperation scheme, inc. China the largest economy in Asia, and Japan the second-largest, as well as some developed economies like South Korea, Singapore, Indonesia and Thailand presently in very strong momentum of developments. This region covered possesses a full economic cycle from raw materials to processing \& manufacturing and consumption. For the regional financial cooperation, the $[10+3]$ can be a platform. Asia needs it, and a regionalized economy needs it, too. But the pessimism is that the major Asian nations are 
lack of mutual trust that has to be strengthened. I am looking forward to seeing the future ACU, and the free flow of both labors and capital in Asia [12]".

According to Mundell's theory, the more FTAs and the more increased flow of production elements. Therefore, Asia does need a regional common currency. The trend of regional integration in Asia shows that it is only a matter of time to see the ACU becoming true. Just as Mr. LONG Yong-Tu, the former SecretaryGeneral of the Boao Asia Forum, pointed that issuing the ACU in one day is a worthy goal to pursue.

\section{b) Possibility for Setting up the [10+4] Economic Community}

On December 15, 1997, the first informal meeting of leaders of the ASEAN, China, Japan and South Korea had been held in Malaysia. The 13 leaders of Asian nations met and discussed the prospect of East Asia in the 21st century, as well as the problems faced for achieving a broad consensus. Since then, the "10+3" regional cooperation process was launched initially. So far, the "10+3" has established 65 dialogues and cooperation mechanisms, conducting respectively the issues of foreign affairs, finance, economy, labor, agriculture and forestry, tourism, environmental, health and combating transnational crime, culture, energy, information and communication, social welfare and development, science and technology, youth, media, and education; and had 17 ministerial meetings. The meetings of foreign ministers and finance ministers are held annually, and the state leaders meet regularly, etc. [13].

On November 29, 2004, the 8th meeting of the "10+3" had been held in Vientiane, Laos, and a longterm target was identified to establish the East Asian Economic Community, deciding to kick off the East Asia FTA feasibility study program. In 2010, in Cheju Island, South Korea, in the [10+3] Summit, the leaders of the three nations declared that a study program about FTA and relevant issues by government-appointed representatives, economists and scholars of the three countries, should be completed by mid-2012. In the Summit, it had been suggested that the China's State Council Development Research Center (CSDRC), the National Development Research Institute (NIRA, since
2009 it changed the name as the Japan Economic and Trade Research Organization - JETRO), and the South Korea International Economic Policy Institute (KIEP) working respectively on behalf of their governments for providing policy advises [14]. On April 11, 2017, China, Japan and South Korea resumed talks on FTA in Tokyo, according to the Nikkei Business Daily reports. In addition to the customs and tariff in commodities trading, service trade and investment, the three nations shall also discuss how to advance the framework of negotiations in the future.

The "10+3" negotiations have gone through nearly twenty years. Although agreement not yet finalized, it has become one of the most profound and significant FTA initiative in Asia, including developed countries, emerging economies and developing countries; geographically ranging from northeast to southeast Asia, with more than 3 billion people accounting for $57 \%$ of the Asia total; taking for $88 \%$ of Asia total GDP, more than 50\% of Asia total trade volume overtaking the NAFTA and EU combined total [15].

For the $[10+4]$ as focused in the paper, as early as in 1998, India's former Prime Minister Behari Vajpayee had ever put forward a concept of Asian Economic Community. Later on, his successor Manmohan Singh further redefined the idea, formally proposing the existing mechanism of the "10+3" to $[10+4]$, plus India. In 2004, in the 3rd India-ASEAN Business Summit, Singh pointed out, "The future Asian Economic Community should include China, Japan, South Korea, India and the ASEAN. Indian scholars even used the combination for the word JACIK, namely Japan, ASEAN, China, India and Korea, as the Chesapeake initials [16]. On October 16, 2016, Indian Prime Minister Modi said in Beijing, "Asia has become the center of the global economic development, and Asian nations have the responsibility to join hands to make the 21 st century the Asian century. The [10+4], ranging from East Asia, Southeast Asia to South Asia formed mainly by developing countries, shall help to change the injustice situation of the world and to change the current international economic order [17].

Table 1: Comparison of Economic Scales of the [10+4], EU and NAFTA

\begin{tabular}{|c|c|c|c|c|c|}
\hline Year of 2003 & EU & NAFTA & ASEAN & {$[10+3]$} & {$[10+4]$} \\
\hline GDP(Trillion USD) & 10.069 & 11.716 & 0.672 & 7.014 & 7.613 \\
\hline Taking the World Total (\%) & $(27.69)$ & $(32.23)$ & $(1.85)$ & $(19.29)$ & $(20.94)$ \\
\hline Export(Trillion USD) & 2.603 & 0.996 & 0.447 & 1.552 & 1.607 \\
\hline Taking the World Total (\%) & $(34.80)$ & $(13.32)$ & $(5.98)$ & $(20.75)$ & $(21.48)$ \\
\hline $\begin{array}{c}\text { Foreign Exchange Reserves } \\
\text { (Trillion USD) }\end{array}$ & 0.545 & 0.206 & 0.244 & 1.516 & 1.618 \\
\hline Population(Billion) & 0.418 & 0.323 & 0.537 & 2.001 & 3.065 \\
\hline Taking the World Total (\%) & $(6.66)$ & $(5.15)$ & $(8.56)$ & $(31.91)$ & $(48.87)$ \\
\hline
\end{tabular}

Sourced: Mario Lambert, An Oveniew of Economic Cooperation and Integration in Asia, p.36. 
Despite the [10+3] FTA has not yet formally reached, four major Asian nations of China, Japan, South Korea, and India, have respectively signed with the ASEAN the FTA agreements, and all are in the frame of RCEP. So, in the next step, the $[10+4]$ mechanism shall be possible.

\section{Conditional Analysis of the MONETARY INTEGRATION WITHIN THE $[10+4]$}

The regional monetary integration index is rather complicated. The importance of each index shall be elaborated one by one in this paper. Based on referential parameters in Europe in the early stage (referring the year of 1992) of the monetary integration, comparing with the Asian regionalization (mainly the year of 2015), in the resumed scope of the [10+4] in indexes such as the purchasing power, trade volumes, foreign trade dependency, capital liquidity, policy coordination, movement of production elements, economic level of convergence, and political conditions in the domain. In this way, the feasibility studies of the single currency zone of the $[10+4]$ are established.

\section{a) Purchasing Power Analysis}

One of the purposes of the regional economic integration is to create a unified market which is regarded as the gain of the regionalization. The importing capacity represents purchasing power. Whoever holding the lever shall be more prevailing in trade talks. As shown in Table-2, in 2015, the [10+4] imported total of $\$ 4.3026$ Trillion, comparatively, in the same year that of the EU be \$1.95 Trillion and \$ 0.996 Trillion of the NAFTA. These provide favorable conditions for the implementation of regional monetary unification in the $[10+4]$. Also, in 2015, the GDP contribution of the $[10+4]$ to the global economy was bigger than that of the EU and NAFTA respectively.

Table 2: Purchasing Power Comparisons of the [10+3], [10+4], EU and NAFTA

\begin{tabular}{|c|c|c|c|c|}
\hline 2015 & EU & NAFTA & "10+3" & "10+4" \\
\hline $\begin{array}{c}\text { GDP } \\
\text { (Trillion USD) }\end{array}$ & 14.5 & 20.57 & 20.81 & 22.99 \\
\hline Proportion of the World Total(\%) & $(21.56)$ & $(30.59)$ & $(30.95)$ & $(34.19)$ \\
\hline $\begin{array}{c}\text { Imports } \\
\text { (Trillion USD) }\end{array}$ & 1.95 & 0.996 & 3.9829 & 4.3026 \\
\hline
\end{tabular}

Sourced: ZHANG Lujing. Three FTA Pillars in Europe, America and Asia, China Economic Weekly, July 12, 2015

\section{b) Internal Trade Volumes Analysis}

The greater the internal trade volume be, the more costs can be reduced by the economic unification. Moreover, the integration helps to keep the price stability of countries in the region to make the exchange rate adjusting the balance of payments in participating countries.

The first phase of the European monetary integration began in the early 1990s. In the duration, the total internal trade of the 12 countries in the EEC was about \$29,722 Billion (1992: \$14,518.6 billion for exports; $\$ 15,202.7$ billion for imports); the total GDP was $\$ 68,412$ billion; and internal regional trade about $43 \%$ of GDP total, at the historical time of the exchange rate and price [18].

Foreign trade dependence degree is one of the key indicators to measure a country's economic opening to the world. In 2015, the annual internal trade volume of the $[10+3]$ was $\$ 1.3$ trillion. In the same year, the bilateral trade volumes of India with China were about \$100 billion, with the ASEAN \$100 billion, with Japan \$25 billion, and with South Korea $\$ 30$ billion, respectively. So, the total internal trade volume of the $[10+4]$ was about $\$ 1.555$ trillion in the year of 2015 . In 2015 , total GDP volume of the $[10+4]$ had been about $\$ 22$ trillion as calculated by the reference of "the total GDP volumes of Japan, South Korea, India and the ASEAN were about $\$ 11$ trillion in 2015, equal to China's GDP size [19]". In this way, the internal trade volume, being calculated as accounting for about $14 \%$ of overall GDP of the $[10+4]$, has a great potentiality to grow as generated by the large population in the region. Considering the $\$ 1.555$ trillion of internal trade volume within the scope of the $[10+4]$ in 2015 , the monetary unification can reduce the trading costs in the regional domain largely.

Table 3: Internal Trade Volumes of [10+4] Comparison with EU and NAFTA

\begin{tabular}{|c|c|c|c|c|}
\hline & $\begin{array}{c}\text { Internal Trade Volumes } \\
\text { (Trillion USD) }\end{array}$ & $\begin{array}{c}\text { GDP } \\
\text { (Trillion USD) }\end{array}$ & $\begin{array}{c}\text { Internal Trade Volumes } \\
\text { / GDP }\end{array}$ & $\begin{array}{c}\text { Populations } \\
\text { (100 million) }\end{array}$ \\
\hline 1992:NAFTA & 0.306 & 6.45 & $4 \%$ & 4.21 \\
\hline $\begin{array}{c}\text { 1992: } \\
\text { 12 Nations of EU }\end{array}$ & 2.9722 & 6.8412 & $43 \%$ & 4.18 \\
\hline 2015:[10 + 4] & 1.555 & 11 & $14 \%$ & 30.065 \\
\hline
\end{tabular}

Source: List of Global Goods Import \& Export in 2015, World Trade, 2016(4) 
According to the statistics by De la Torre and Kelly, in the years 1970-1985 in the ten countries of the EEC, the weight of the internal trade volume against the total GDP increased by an average of 6.8 percent, and the external trade grew at an average annually by 5.2 percent[20]. For the same, the Asian economic integration shall further boost the internal regional trade volume and economic growth. In spite of the foreign trade dependency in the current $[10+4]$ scope still lag behind the EU of 1992, the total trade volume of [10+4] has been more than that of the EU figure in 1992. The proportions of total trade volume accounting for total GDP, and internal trade volume accounting for total foreign trade, are both increasing in recent years in the $[10+4]$. Therefore, it could be concluded that the trend of internal trade volume satisfies the requirements of the $[10+4]$ FTA scheme, and the regional monetary cooperation can be carried out at sub-levels in this stage.

\section{c) Comparative Analysis of Capital Flows}

Regional economic integration refers to, within the domain, production materials or resources can freely flow, so to optimize the allocation of production elements or resources. In a highly integrated international financial market, the free movement of capital among member states is one important criterion. Capital flows can be divided into the Foreign Direct Investment (FDI), Foreign Portfolio Investment (FPI) and International Loan Lending (ILL). The three are the main channels of international capital flow.

The free movement of capital in the EU permitted in December 1991 is a legal provision in the Fourth Chapter (article 56 to 60) in the EEC Treaty, and the Article 56 is the core stipulation for the capital flow. It prohibits any restrictions on capital and payments flows among and between member states and third countries.
To be clear, Chapter 4 of the EEC Treaty is not only limited to capital flows, but also free payments [21]. Also, in recent years within the EU, the private equity funds cross-border investment has developed rapidly, becoming a new way of capital flow. The free movement of capital has become the central pillar of the EU as a single market.

On May 13,2012 , in the $5^{\text {th }}$ Session of the trilateral leaders meeting of China-Japan-Korea, the three parties signed a document named the Agreement of the Governments of the People's Republic of China, Japan and Republic of Korea on Investment Convenience, Promotion, and Protection. In 2015, ten member nation leaders of the ASEAN signed agreement announcing the founding of the ASEAN Economic Community in Kuala Lumpur, in purpose to create a freer environment for trading and capital flow in the region where there are 625 million people, with an economic capacity of $\$ 2.6$ trillion. The communiqué states a: We must now ensure a freer environment to remove barriers for investment growth". Presided over the summit, Mr. Najib Razak, the Malaysian Prime Minister then pointed out. In fact, we have eliminated the trade barriers among the ASEAN nations, now we must ensure that a more liberal environment, and make sure the removal of the barriers that hinder investment growth [22].

In the year 2017, China's total debt has been equivalent to $250 \%$ of GDP, still rising [25]. As the largest economy in the $[10+4]$, China is now facing rapid growth of the liabilities, as shown in Figure 2. China's size of the finance shall have impact on the global economic stability. Therefore, China must, first of all, rebalance its economy and maintain its financial system stable. The capital free flows are not possible for China for the time being, nor within the $[10+4]$.

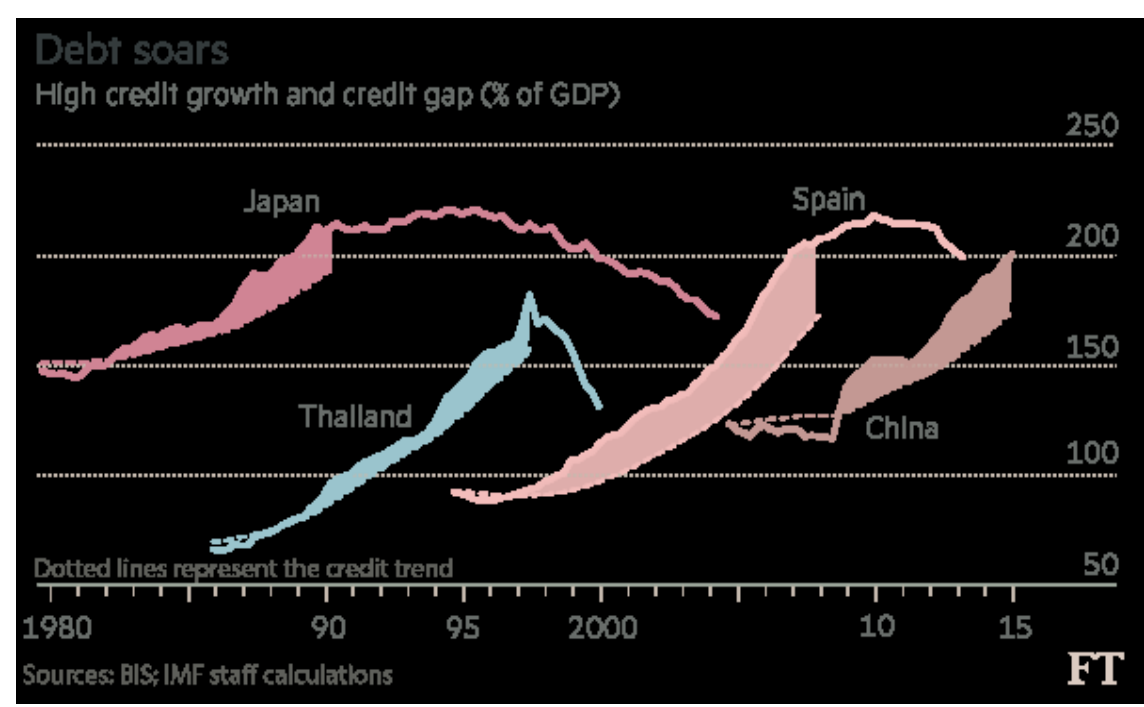

Source: Martin Wolf. How China to get rid of the debt trap? Financial Time, April 13, 2017

Figure 2: Dept Situations of China, Japan, Thailand, and Spain 
Concurrently, Asia's regional economic integration is at the lower level of PTA and FTA. Especially after the Asian financial crisis, Asian countries strengthened the capital control, to prevent the impact of international hot money. At present, while promoting the "Belt and Road" strategic initiative, the Chinese government is pushing the RMB internationalization. However, due to the RMB depreciation happened recently, the government strengthened the capital controls, to have made the RMB internationalization pace slowed down. As a result, among the Asian countries (even within the $[10+4]$, the international financial market development level is still rather low. Therefore, the criterion of the free flow of capital is not up to the standard by now and shortly.

\section{d) Liquidity of Production Elements}

According to Mundell's theory, in the same currency zone, if the exchange rate policy lever be used to adjust the demand side, to maintain price stability and sufficient employment rate of all member countries, there must be the high liquidity of the production elements adjusting demand shifting. Not allowed that timely and effectively, it will affect the balance situation of international payments and economic stability of the member nations in the monetary integration process.

Among the 10 ASEAN countries, the economic development levels vary so big, in high similarity of industrial structures, lower production elements mobility. All these factors hindered the further development of the cooperation. Prof. YANG Mu, a senior fellow of the Institution of East Asia Studies of the National University of Singapore, pointed out that internal problems of the ASEAN are mainly the economic gap between its six old members and the four new ones. In spite that Vietnam's economic development caught up in recent years, the gap is growing [23]. The [10+3] FTA agreement is not yet signed; even the internal market for mobility of production elements within the ASEAN is still in its infancy stage. In the term of the free flow of labors alone, there are still faced a lot of restrictions. So it will take a longer time for the $[10+4]$ scheme be finalized.

\section{e) Policy Coordination Analysis}

The ASEAN countries, as well as the four Asian nations, China, Japan, Korea, and India, all have their interest considerations in monetary and financial fields, but the main factors affecting their respective decisionmaking are the same, both the economic and noneconomic aspects. The opening feature of the FTA is a double-edged sword, which can be great opportunity for countries to improve their competitiveness, and also can be a striking force to the weak economic sectors. At the same time, in the $[10+4]$ domain, besides the diversified ed economic development levels, all countries involved have certain distances to the FTA standard. The pressures of FTA standardization may become the driving force for their economic transformation and industrial upgrading within the region, and may also trigger their economic and social tensions. The non-economic factors can be more deeply influential because the FTA shall be an agreement containing the political power games and ideologies behind the competitions.

In the process of monetary integration, policy coordination among member states plays a decisive role. According to the standard model of MundellFleming, one nation's monetary and fiscal policy has certainly a spillover effect. If two nations play different policies which might bring negative effects to each other, affecting their cooperation relations. At present, no uniformed monetary and fiscal policy has been established in the ASEAN, and nor in ASEAN related FTAs with China, Japan, South Korea and India. Although on May 3, 2016, the ASEAN Finance Ministers' Summit stating that the monetary and fiscal structural policy tools will be adopted uniformly when necessary to promote and booster the whole economic growth to make sure the regional economy continuing to grow at a relatively high rate, as the global economic engine [24]. But the current situation shows that, due to the low level of regional economic integration, Asian countries now still have gaps in their policy coordination.

\section{f) The Convergence Analysis on Economy Levels}

In the process of regional monetary integration, if economic levels and economic structures of the member countries are approximately the same, the external impacts and effects on the countries will be symmetrical. Thus, the same or similar monetary and financial policies can be adopted to offset shocks, reducing the pressure on the entire region. But, if the economic development levels are too different, the costs undertaken by member countries are different too, so that the monetary integration shall be unstable and would face big problems. 
Table 4: List of GDP and Growth Rates of Nations of [10+4] in 2015

\begin{tabular}{|c|c|c|c|}
\hline 2015 & $\begin{array}{c}\text { GDP } \\
\text { (100 Million in USD) } \\
\text { by Type of Expenditure }\end{array}$ & $\begin{array}{c}\text { Population } \\
(10,000)\end{array}$ & $\begin{array}{c}\text { Per Capita GDP } \\
\text { (USD) }\end{array}$ \\
\hline Japan & $43,830.8$ & $12,657.3$ & 34629 \\
\hline Korea & 162.8 & $2,512.6$ & 27397 \\
\hline China & $111,584.6$ & $137,604.9$ & 8109 \\
\hline India & $21,162.4$ & $131,105.1$ & 1614 \\
\hline Singapore & $2,927.3$ & 560.4 & 52239 \\
\hline Indonesia & $8,619.3$ & $25,756.4$ & 3346 \\
\hline Thailand & $3,951.7$ & $6,795.9$ & 5815 \\
\hline Malaysia & $2,962.8$ & $3,033.1$ & 9768 \\
\hline Philippine & $2,924.5$ & $10,069.9$ & 2904 \\
\hline Vietnam & $1,932.4$ & $9,344.8$ & 2068 \\
\hline Cambodia & 180.5 & $1,557.8$ & 1159 \\
\hline Brunei & 129.3 & 42.3 & 30553 \\
\hline Burma & 626.0 & $5,389.7$ & 1161 \\
\hline Laos & 125.9 & 680.2 & 1850 \\
\hline
\end{tabular}

Source: National Accounts of UN, 2015

As Table 4 shows, the three ASEAN member nations, Burma, Cambodia, and Laos, are the poorest in the weak economic base and less competitiveness. Economies of the three have many similar characteristics, such as low productivity levels, agriculture-oriented, forestry, manufacturing industries underdeveloped, and single economic structures. Their foreign trades are dominated by exports of resource materials, with low value-added and low technical content. In the three, the legal systems are not sound, and the investment environments need to be improved. Their workforce is rich but lacks training and education, and infrastructures lag behind, etc. All in all, the economic structures and the development levels are in big difference within the 14 countries of the $[10+4]$. Once implementing the uniformed monetary policy, countries will undertake a larger difference between costs and benefits. Thus conflicts shall taking place among them.

\section{g) Political Conditions Analysis}

Political relations among the Asian countries are complicated, especially that of the Sino-Japan, the SinoIndia, China-South Korea, Japan-South Korea, for this or that reasons. Development of the mechanism of [10+4] depending on the further development of the [10+3], whether or not China is willing to accept India, as well as and situation of the four bilateral relations, particularly the Sino-Japan relation. The ASEAN's rich experience in regional cooperation is valuable, and its role of the axis will be a factor for successes of both the $[10+3]$ and the $[10+4]$. Though not Asian-wide, the $[10+4]$ mode for future Asia and the Asia-Pacific cooperation will be of important influence. Normalized and harmonious international relations are the necessary conditions for regional economic cooperation. The monetary integration needs a certain high degree of political cooperation and some necessary sovereignty transfer. However, because of different political systems and different ethnicities, religious beliefs and cultural diversity of 14 countries within the $[10+4]$, mutual understanding, and trust are very necessary. All these differences can cause problems, making it difficult to reach an agreement.

To compare above-mentioned conditions in Asia at present with the situation of Europe at the time starting to use the currency EURO, it can be concluded that within the $[10+4]$ the purchasing power and the internal trade volumes have only reached the very basic criteria for the implementation of regional monetary unification. However, the national economy levels and political conditions still cannot meet the requirements. The difficulties in achieving the free movement of capital and production factors can affect the breadth and depth of the regional monetary integration. Therefore, it can be foreseen that the building up an Optimal Currency Zone in Asia has quite a long way to go. However, the conditions clearly show that the lower levels of currency integration can be done in stage by stage strategy.

\section{Suggestions for the Asian Currency Unification In THE [10+4] DOMAin}

According to the above analysis, although at a good momentum, the situation shows that economic 
integration in Asia still in the primary stage, it has not yet provided the necessary conditions for the regional monetary integration in a wide range. Despite the obstacles faced, the integration can be implemented at a surface level slowly in stages within the $[10+4]$ range.

\section{a) Enlightenment from European Unification}

In 1945, when Europe still in ruins, the European countries kicked off their regional cooperation plan in a new way of thinking and a forward-looking attitude dealing with their conflicts and disputes. It was then that European political unity and economic integration began with the active advocacy led by France and Germany. Gradually, Europeans are more and more aware that a united Europe becomes a necessary condition for sustained peace and prosperity. So far, the EU has become the world's largest market and a regional political force that can compete with the US.

In the case of implementation process, though, every member of the EU had a different degree of regret over the abandonment of their currencies. The Germans, in particular, were deeply hesitant about giving up the Mark that had been of stability and strength. However, to gain international competence, they would give up their national interests and eventually accepted the EURO because Germans know that neither the Deutsch Mark nor the French Franc can compete against the US Dollar alone, but the EURO can. Further expansion of the EU application means more than just geographic sake, but an economic power. The establishment and running of the EU is a good and positive model of the regional socialeconomic cooperation, providing experiences and lessons for Asia. Although the Brexit recently happened, it should not be regarded as abnormal, because the integration was an open process itself. The four Asian nations, China, Japan, South Korea, and India all actively and respectively promoting and participating in the Asian regionalization, should learn from Germany and France, to shelve disputes, settle the conflicts through negotiations, and to share the responsibility of acting as a locomotive for the regional integration process.

\section{b) Future Asia's Major Currency Pattern}

Since Japan became a member of the IMF in 1964, the Japanese Yen had been used in the international trade settlements. In 1980, Japan amended her Foreign Exchange Law, and the Yen entered into a preliminary phase of liberalization. In 1984, the YenDollar Committees were established and signaled as the beginning of the Yen's move towards internationalization. Presently China is accelerating the $\mathrm{RMB}$ internationalization process, development trends show that China's RMB will also become an international reserve currency. China's total economic capacity and the foreign trade volume have both surpassed that of Japan. Not just as the world's largest exporter for goods,
China is also the world's largest capital exporter accounting for $21 \%$ of the global total in 2010, accumulated in cross-border trade settlements and offshore market financing, as well as in the open market of foreign direct investment and onshore financial markets. By the end of 2015, China had successively signed currency SWAP agreements with monetary authorities of 30 countries and regions to promote the more use of the RMB in bilateral trades with a total amount of 3.1102 trillion Yuan RMB [25]. According to a report published, after the RMB officially gained the IMF Special Drawing Rights (SDRs) as one of the baskets of currencies, foreign central Banks shall increase their $\mathrm{RMB}$ as official foreign exchange reserves gradually. It is foreseen that, three years later, the demands of the RMB will rise to $4 \%$ of the total share of global foreignexchange reserves, same as the Japanese Yen [26].

Since June 1, 2012, the Japanese Yen became one more competitive currency to trade directly against the RMB. It is a win-win measure for both. The RMB directly dealing with the Yen not only help to expand and deepen the bilateral trade and investment activities, but also a significant step of the RMB internationalization. It will, at the same time, increase global status of the two currencies in the world market. When two currencies, US Dollar and EURO, becoming less stable today, the bilateral monetary cooperation of Sino-Japan will bring a global influence in the world monetary system. It also shall help the Asian nations to gain the speech right.

It can be seen that before the monetary regionalization, a diversified currency system in Asia shall be developed with the Japanese Yen and Chinese RMB as settlement and reserve currencies, but the US Dollar will be dominated still.

\section{c) Procedures of the Monetary Unification in Asia}

The Birth of the EURO and the European monetary integration have been the most significant events in the modern economic and financial histories. The European monetary integration broke the narrow definition of the original national sovereign currency concept, representing a higher level of regionalization. It is one innovative breakthrough in the economic theory. European monetary integration provided beneficial experiences and references for Asia. Although the Yen and the RMB have become an international Currency, Asia still needs a unified currency to be commonly accepted by all Asian countries, i.e. the ACU - the Asian Currency Unit.

\section{i. Institutional Construction}

Based on the existing conditions and trends of Asia, it suggests that the institutions concerned should establish for the implementation of the monetary unification step by step. The immediate priorities are:

1) Research institutions of India and the ASEAN could be invited to join the team formed by the representatives of China, Japan, and South Korea, 
i.e, the $[10+3]$, including the China's State Council Development Research Center (CSCDRC), the Japan Economic Trade Restructuring Organization (JETRO) and the Korea International Economic Policy (KIEP) doing the research and produce monetary integration policy study reports for their governments respectively.

2) Based on the Common Reserve Fund scheme by the Protocol of the Chiang-Mai Initiative, the Asia Monetary Fund (the AMF) should be established with the duty to monitor the currency exchange and the trading in Asia, to provide technical and financial assistance, to make sure the function of financial system operating within the $[10+4]$. The establishment of the AMF shall be of a significance to maintaining the regional economic and financial stability and will have a positive impact on reforming and improving the international system.

10 3) To set up the Asia Common Currency Committee formed by representatives of the central banks of the ASEAN, China, Japan, Korea, India, as well as the $\mathrm{ADB}$ and AIDB, guide the implementing the regional monetary integration.

ii. The ACU Designing Basis and Value Calculation

Enlightened by the ADB works done in 2005, the value of the ACU is herewith recalculated by combining 14 national currencies of the [10+4], through consultations with the ADB officials, and scholars of Japan and India.

We are considering about the economic levels variety among the member nations within the [10+4]. Therefore, taking the weight of national GDP against the total GDP of the 14 is a reasonable approach. First of all, choosing the period of 5 years (2011-2015) and the total GDP figures of the 14, and then calculating weight ratios of the 14 single GDP against the total GDP respectively in the average weighted method. Finally, according to the concurrent market exchange rates of 14 national currencies against that of the US Dollar, the value of ACU against the US Dollar is calculated.

Table 5: Calculations of Exchange Rate of ACU and USD

\begin{tabular}{|c|c|c|c|c|c|c|c|c|c|}
\hline & \multirow{3}{*}{ Nations } & \multicolumn{5}{|c|}{$\begin{array}{l}\text { 2011-2015,Weight of the Total GDP of } \\
{[10+4] \text { Respectively }}\end{array}$} & \multirow{3}{*}{$\begin{array}{c}\text { Averaged } \\
\text { Weight }\end{array}$} & \multirow{3}{*}{$\begin{array}{c}\text { Exchange } \\
\text { Rate }\end{array}$} & \multirow{3}{*}{$\begin{array}{c}\text { ACU/USD } \\
\text { Exchange } \\
\text { Rate }\end{array}$} \\
\hline & & \multirow{2}{*}{$\begin{array}{c}2011 \\
\begin{array}{c}\text { GDP占 } \\
\text { 比 }\end{array}\end{array}$} & \multirow{2}{*}{\begin{tabular}{|c|}
2012 \\
$\begin{array}{c}\text { GDP占 } \\
\text { 比 }\end{array}$
\end{tabular}} & \multirow{2}{*}{$\begin{array}{c}2013 \\
\begin{array}{c}\text { GDP占 } \\
\text { 比 }\end{array}\end{array}$} & \multirow{2}{*}{\begin{tabular}{|c|}
2014 \\
$\begin{array}{c}\text { GDP占 } \\
\text { 比 }\end{array}$
\end{tabular}} & \multirow{2}{*}{$\begin{array}{c}2015 \\
\begin{array}{c}\text { GDP占 } \\
\text { 比 }\end{array}\end{array}$} & & & \\
\hline & & & & & & & & & \\
\hline 1 & Malaysia & $1.68 \%$ & $1.56 \%$ & $1.62 \%$ & $1.56 \%$ & $1.50 \%$ & $1.58 \%$ & 0.2375 & \\
\hline 2 & Indonesia & $5.09 \%$ & $4.51 \%$ & $4.81 \%$ & $4.24 \%$ & $4.13 \%$ & $4.56 \%$ & 0.000077 & \\
\hline 3 & Thailand & $2.08 \%$ & $1.88 \%$ & $1.97 \%$ & $1.79 \%$ & $1.79 \%$ & $1.90 \%$ & 0.0284 & \\
\hline 4 & Philippine & $1.28 \%$ & $1.29 \%$ & $1.23 \%$ & $1.36 \%$ & $1.43 \%$ & $1.32 \%$ & 0.0206 & \\
\hline 5 & Singapore & $1.56 \%$ & $1.42 \%$ & $1.33 \%$ & $1.47 \%$ & $1.41 \%$ & $1.44 \%$ & 0.7211 & \\
\hline 6 & Brunei & $0.09 \%$ & $0.09 \%$ & $0.08 \%$ & $0.07 \%$ & $0.06 \%$ & $0.08 \%$ & 0.7213 & \\
\hline 7 & Vietnam & $0.74 \%$ & $0.71 \%$ & $0.73 \%$ & $0.89 \%$ & $0.95 \%$ & $0.80 \%$ & 0.000045 & 000 \\
\hline 8 & Laos & $0.05 \%$ & $0.05 \%$ & $0.05 \%$ & $0.06 \%$ & $0.06 \%$ & $0.05 \%$ & 0.0001 & 0.0880 \\
\hline 9 & Burma & $0.31 \%$ & $0.27 \%$ & $0.28 \%$ & $0.30 \%$ & $0.31 \%$ & $0.30 \%$ & 0.0007 & \\
\hline 10 & Cambodia & $0.08 \%$ & $0.07 \%$ & $0.07 \%$ & $0.08 \%$ & $0.08 \%$ & $0.08 \%$ & 0.0002 & \\
\hline 11 & China & $43.95 \%$ & $42.24 \%$ & $43.17 \%$ & $49.58 \%$ & $52.02 \%$ & $46.19 \%$ & 0.1485 & \\
\hline 12 & Japan & $35.35 \%$ & $30.62 \%$ & $28.64 \%$ & $22.05 \%$ & $19.73 \%$ & $27.28 \%$ & 0.0096 & \\
\hline 13 & S-Korea & $6.72 \%$ & $5.93 \%$ & $5.89 \%$ & $6.77 \%$ & $6.67 \%$ & $6.40 \%$ & 0.0008 & \\
\hline 14 & India & $1.01 \%$ & $9.37 \%$ & $10.11 \%$ & $9.79 \%$ & $9.86 \%$ & $8.03 \%$ & 0.0149 & \\
\hline
\end{tabular}

Source: National Accounts of UN, 2015

The formula is in below:

$$
\begin{gathered}
y^{n}=x_{1}^{n}+x_{2}^{n}+\cdots+x_{i}^{n}=\sum_{i} x^{n} \\
z=x_{1}^{1}+x_{2}^{1}+\cdots+x_{i}^{1}+x_{1}^{2}+\cdots+x_{i}^{2}+x_{1}^{n}+\cdots+x_{i}^{n}=\sum_{i}^{n} x
\end{gathered}
$$




$$
\mathrm{A}=\frac{y^{1} * c^{1}+y^{2} * c^{2}+\cdots+y^{n} * c^{n}}{z}=\frac{\sum(y * c)}{\sum_{i}^{n} x}=\frac{c^{1} * \sum_{i} x^{1}+c^{2} * \sum_{i} x^{2}+\cdots c^{n} * \sum_{i} x^{n}}{\sum_{i}^{n} x}
$$

$x_{i}^{n}$, stands for GDP of $n$ Nations in $i$ Years, $n$ for Number of Nations, $i$ for Number of Years

$y^{n}$, stands for total GDP of a nations in $i$ Years

$z$, stands for total GDP for all nations in iyears

$c^{n}$, stands for the exchange rate of $n$ Naation

A, for value of the ACU

d) The Prospect of Asian Regional Monetary Integration

The basic theory of regional economic integration tells that the process usually consists of

seven stages (see Figure 2). It has to undergo stages of PTA, FTA, CU, CM, EU and EMU, one by one, finally reach to $P E U$, the political and economic alliances.

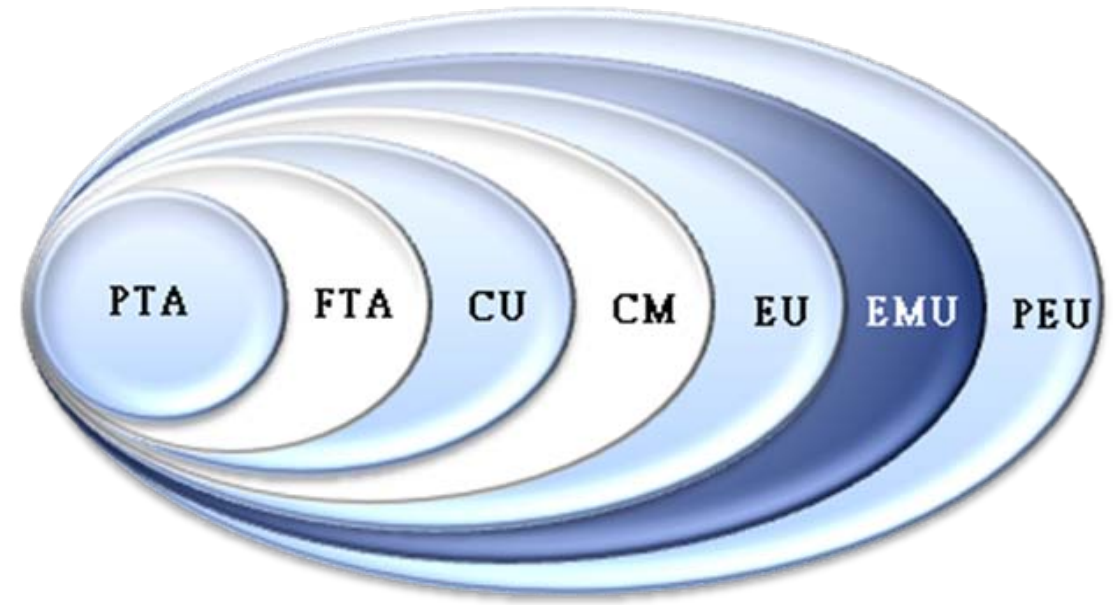

Figure 2: The Regional Monetary Integration in Stages

PTA $=$ Preferential Trade Agreement

$\mathrm{CU}=$ Customs Union

$\mathrm{EU}=$ Economic Union

$P E U=$ Political and Economic Union

The EMU is the goal of economic integration. It requires all participating states go for tariffs, trade and market integration, establishing a supranational institution, adopting a common stand in the international economic decision-making, exercising a unified monetary policy, and forming the unified financial management institutions, in order to realize the comprehensive regionalization in all fields of the economies.

As long as the trend is going and steps taking, the currency integration in the Asian $[10+4]$ will surely become a reality in the future. The integration process will step by step increase the level and quality of FTA in the region. A diversified international monetary structure resulting from the emergence of the ACU will inevitably make a profound impact on the world economic order in the future.

\section{e) The Proposal To Set Up the ACU Experimental Zones}

The regional integration has three features, i.e, the fuzzy boundaries, the sovereign transfer and the
FTA $=$ Free Trade Agreement

$\mathrm{CM}=$ Common Market

$\mathrm{EMU}=$ Economic and Monetary Union

equality. The experience of the European integration has fully verified the features. Among most European countries there had been territorial disputes that all have historical evidences to prove the sovereignty, such as the Auckland Islands, the Corsica, the Basque, the Sardinia, the Danzig, and the East Prussia, and so on. The supranational concept makes the Europeans shelved their disputes, to have the Europe rebuilt, because the Europeans believing a national competence relying on science and technology, culture and economy, but not the concept of land wise.

The regional economic integration at the same time is also a peaceful process because all parties involved have to agree to a basic principle, i.e, any disputes to be solved in the process by way of negotiations, not through the wars. The regional monetary integration has peace function too. Asian countries could set up some small ACU Experimental Zones to promote the integration as initial steps when it does not yet possess the conditions for region-wide implementation. So the regional peace cause is 
promoted. In this way, the ACU not only helps to build up a true Asian symbol but also provides a peaceful solution to the territorial disputes.

Up on with the above considerations, we suggest to set up the first three small ACU Experimental Zones in Asia in three disputed areas the Diaoyu islands in Chinese (the Senkaku Islands in Japanese); the rocky islets spoken as Dokdo in South Korea and Takeshima in Japan; to choose a small relatively isolated area of disputed land between China and India, to build three tourist places only allowing to use the ACU.

We also propose that the construction of tourist facilities in the three zones could be jointly carried out by three Private Joint Ventures of Mainland of China, Taiwan, and Japan; Japan and Korea (South and North, if possible); China and India, to be managed by the Asian Common Currency Committee. The business proceeds generated partly could be used to establish an Asian Unification Peace Fund. If successful in the three Zones, the model can be applied to all other disputed places in Asia as the second step. In such a zone by zone strategy, the Asia-wide regional monetary integration shall be gradually realized. If in such a way a peaceful settlement of territorial disputes can be made, the ACU shall make contributions for the Asia peace cause.

\section{Conclusion}

Experience of the European regional integration shows that achieving the same in Asia is a necessary condition for sustained peace and prosperity in the region. The prospect of regional economic integration in Asia is reflecting both bright future and problems being faced by all Asian countries. The future is not only depended on the efficient economic integration, but more depends on if the Asian nations can overcome and remove the economic obstacles, to gradually establish a regional market dominated by internal demand.

From the long-term view, Asian nations need to deal with social barriers too. Compared with the economic barriers, the social ones generate resistance to the regional integration process. On March 14, 2017, in Chile, in a new round of TPP meetings without the US presentation and with new step-in of China, it appeared in between Japan and China a situation of tug-of-war [27]. It seems abnormal; as a matter of facts it is normal. It is these disputes among member nations that caused the tensions between a particular interest and the common interests. This tension will make the integration process regularly in the open state, which makes the process in imperfectness and opening in full time. This makes the regionalization peacefully into a democratic process. The national interests should be regarded higher than that of ideological [28], and the common Asian interests should be set higher than the national interests in this logic. The way of thinking can effectively help to resolve disputes over the national sovereignty in Asia.

While the globalization has indeed led to some problems inc. the recent Corona-virus out-breaking worldwide, trends of the economic globalization and the regionalization are still going on. Emergence of the "Counter-Globalization" phenomenon is by no means to turn back to the closed societies and trade protectionism. The getting bigger and more Asian FTAs need the common currency. In a report issued by the Munich Security Conference and Foundation on February 13, 2017, it points out, "Since World War II, world security environment faces the most vulnerable moment by now. The West dominated world may be moving towards the end, and some non-western countries began to reconstruct the world order [29]." The five non-western economies of the ASEAN, China, India, Japan and Korea and ten member nations of the ASEAN within the $[10+4]$ can do the reconstruction, to create an open, new, inclusive all beneficial system.

Mundell's theory is still working with practical value today. The point, taking into consideration academically and politically is, how to balance the globalization and localization.

\section{References Références Referencias}

1. ZHANG Ya-Ming. Asian Countries Accelerate Regional Economic Cooperation Process [N], Xinhua Daily, Nov. 3, 2013.

2. GUO Min. Study on the European Monetary Integration[M], Wuhan University Press, 1996.

3. MIAO Su. Asian Common Currency Prospect with Difficulties [J], Journal of Finance and Securities, 2004 (9), 21.

4. LU Qi-Wen. A Long-Term Goal worth Pursuing [J], Journal of Southeast Asia Studies. 2005 (2), 7.

5. LU Jian-Ren, On the Asian Economic Integration [J], Asia-Pacific Journal, 2012 (5), 32.

6. NI Hao. Looking Forward to see the Asian Common Currency [N], Global Times, Oct. 21, 2016

7. WANG Guo-Zhong. The First Step of Leading the Free World, China will be in the TPP [J/OL], Phoenix News, 2017-03-11.

8. OU Yang. The ASEAN Economic Community Faces Challenges [J], Financial Observation, 2013 (10).

9. WANG Ai-Wen. Asian Currency Unit Test Water, the Combination of 13 National Currencies [N], International Finance, Oct. 26, 2005.

10. PAN Zhong-Min. The Asian Monetary Fund Needs More Time [N], China Daily, 2011-05-23.

11. GU Ming-De. The Significance of the Gradual Internationalization of the RMB [N], Financial Investment, Oct. 10, 2016.

12. ZHOU Qiang-Wu. Speech in Title of "Deepening the Asian Financial Cooperation and Promoting Asian 
Regionalization[R]", sponsored by the Ministry of Finance, China, Oct. 21, 2016.

13. $X U$ Rong-Nai. Meeting of the Leaders of "10+3"[N], Xinhua News Agency, Sept.7, 2016.

14. [14] PAN Pei-Nan. Situation on the ASEAN "10+3 " and "10+6" FTA [EB/OL], Chinese Ministry of Commerce, Website, March 3, 2011.

15. XIN Wen. Mr Li Ke-Qiang's Speech on the 19th Leaders Meeting of "10+3[J]. Xinhua News Agency, Sept. 8, 2016

16. LU Jian-Ren, On the Asian Economic Integration [J], Asia-Pacific Journal, 2012 (5), 32

17. LI Wei. Role of the Think-Tank is to promote the Sino-India cooperation practically $[N]$, China Economic Times, Sept. 27, 2016.

18. DENG Zong-Hao. On the European Integration Process [M], Sichuan University Press, 2011, p 112-114.

19. LUO Qun. GDP Comparison of Asian Countries in 2015 [J], China International Observation, March 2,2015

20. HAI Wen \& Lindert. Development Trend of the Trade Regionalization and Globalization [M], Shanghai People's Publishing House, 2003, p137-138.

21. WANG Shulin. Functions of the Euro [J/OL], Phoenix Finance. 06-1-2009.

22. LIU Kai. The ASEAN Nations signed the Community Agreement [J/OL], Oriental Net Wealth, 20-11-2015

23. LIU Wei. The China \& ASEAN FTA encountered the hidden barriers [J], Journal of OUTLOOK, 2012 (9).

24. DENG Xiao-Dong. The China - ASEAN FTA Developing Further [EB/OL]. Xinhua News Agency, March 9,2017.

25. MIAO Su. List of Agreements signed by China for Bilateral Currency SWAP [J], The Economic Journal, 2015(4).

26. XING Yu-Qing. New Pattern of the International Monetary System after RMB and Yen Traded Directly [N], Shanghai Securities News, May 30, 2012.

27. Robin Harding. China and Japan Fighting for Control Right of the Asian Trade Agreement [N], The Financial Times, March 14, 2017.

28. DENG Zong-Hao. On the European Integration Process [M], Sichuan University Press, 2011, p 112-114.

29. DU Bo. Towards the Post-Western Era: the WesternDominated World Order ended [N], the People's Daily, Feb.16, 2017. 